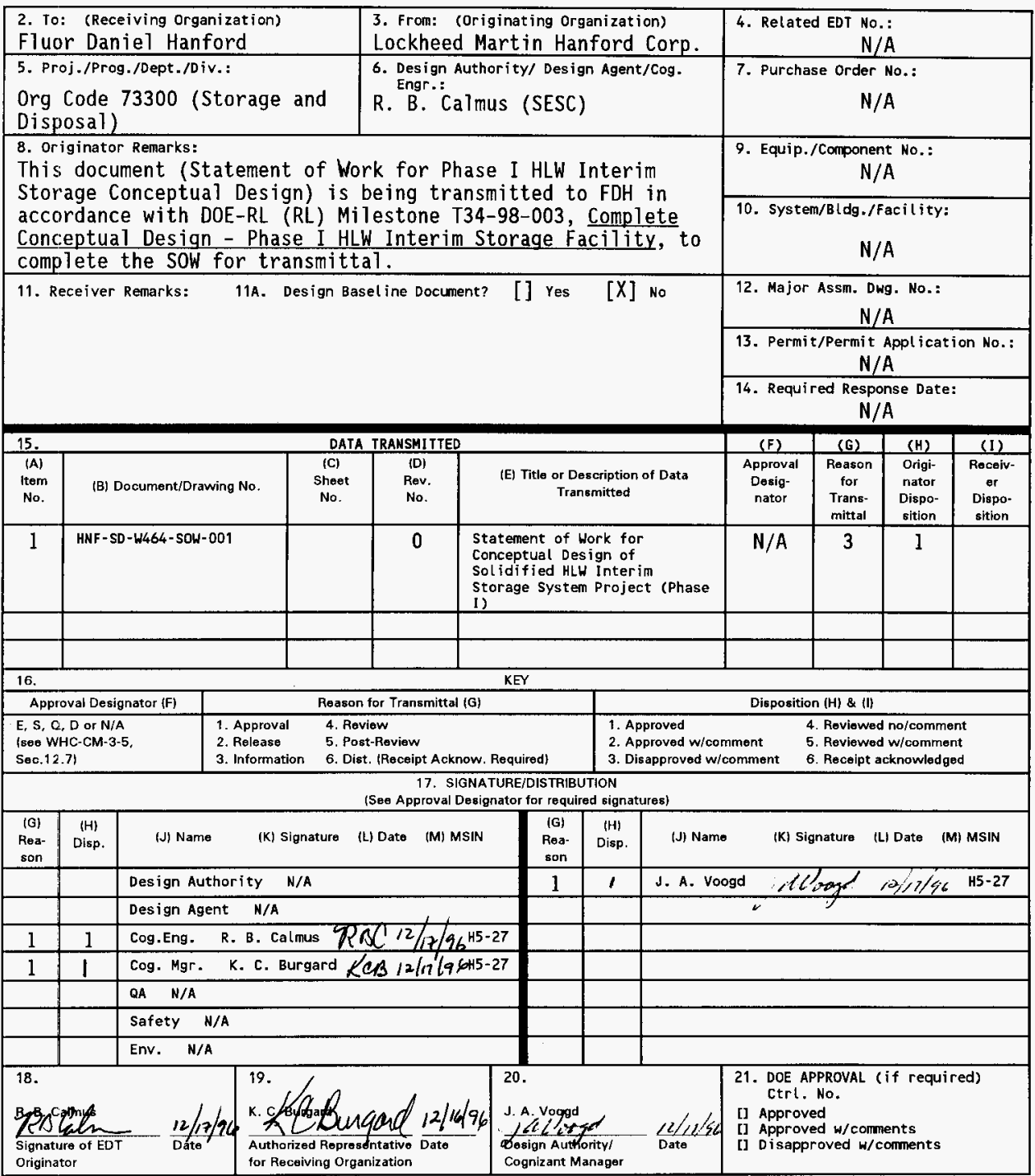

BD-74001-172-2 (05/96) GEF097 


\title{
Statement of Work for Conceptual Design of Solidified High-Level Waste Interim Storage System Project (Phase I)
}

\author{
R. B. Calmus
}

SGN Eurisys Services Corporation, Richland, WA 99352

U.S. Department of Energy Contract-BE-AGOG-87AL-10930 DE-AC06-96RL13200

$\begin{array}{lll}\text { EDT/ECN: } & 619110 & \text { UC: } 2030 \\ \text { Org Code: } & 73510 & \text { Charge Code: } \\ \text { B\&R Code: } & \text { EW3130010 } & \text { Total Pages: } 51\end{array}$

Key Words: High-Level Waste, Statement of Work, Storage, Disposal, Immobilized, Canister Storage Building

Abstract: The U.S. Department of Energy (DOE) has embarked upon a course to acquire Hanford Site tank waste treatment and immobilization services using privatized facilities. This plan contains a two phased approach. Phase I is a "proof-of-principle/commercial demonstrationscale" effort and Phase II is a full-scale production effort. In accordance with the planned approach, interim storage (IS) and disposal of various products from privatized facilities are to be DOE furnished. The path forward adopted for Phase I solidification HLW IS entails use of Vaults 2 and 3 in the Spent Nuclear Fuel Canister Storage Building, to be located in the Hanford Site 200 East Area. This Statement of Work describes the work scope to be performed by the Architect-Engineer to prepare a conceptual design for the solidified HLW IS System.

TRADEMARK DISCLAIMER. Reference herein to any specific comercial product, process, or service by trade name, trademark, manufacturer, or otherwise, does not necessarily constitute or imply its endorsenent, recommendation, or favoring by the United States Government or any agency thereof or its contractors or subcontractors.

Printed in the United states of America. To obtain copies of this document, contact: WHC/BCS Document Control Services, P.0. Box 1970, Mailstop H6-08, Richland WA 99352, Phone (509) 372-2420; Fax (509) $376-4989$
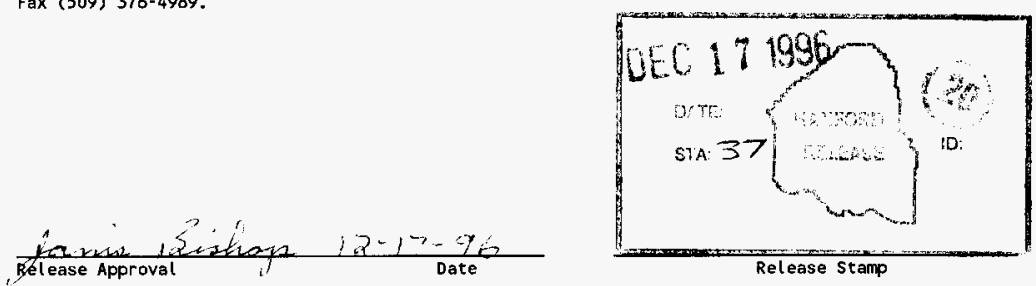

\section{Approved for Public Release}




\section{STATEMENT OF WORK FOR \\ CONCEPTUAL DESIGN OF SOLIDIFIED HIGH-LEVEL WASTE INTERIM STORAGE SYSTEM PROJECT (PHASE I)}

Lockheed Martin Hanford Company Approvals:

Concurrence:

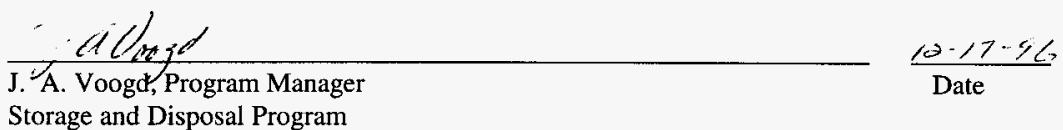

Storage and Disposal Program

Approval:

$$
\text { KC Burgard }
$$

K. C. Burgard, Project Manager

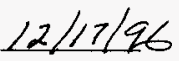
Date

Solidified High-Level Waste Interim Storage System Project (Phase I) 
HNF-SD-W464-SOW-001

Revision 0

This page intentionally left blank. 
HNF-SD-W464-SOW-001

Revision 0

\section{CONTENTS}

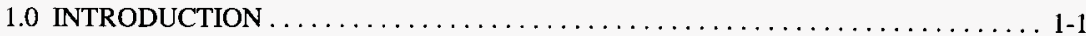

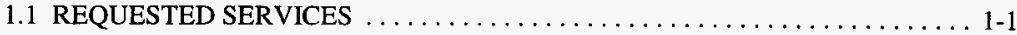

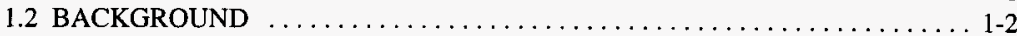

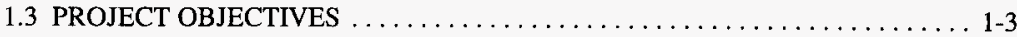

1.4 EXISTING FACILITY AND PROCESS DESCRIPTION $\ldots \ldots \ldots \ldots \ldots \ldots 1-4$

1.5 MAJOR CSB SUBSYSTEMS AND POTENTIAL MODIFICATIONS FOR

HLW INTERIM STORAGE AND TRANSPORTATION $\ldots \ldots \ldots \ldots \ldots \ldots \ldots 1-8$

1.6 HLW INTERIM STORAGE PROCESS DESCRIPTION $\ldots \ldots \ldots \ldots \ldots \ldots .1-11$

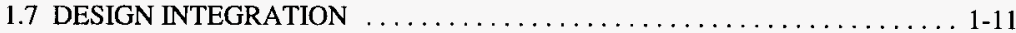

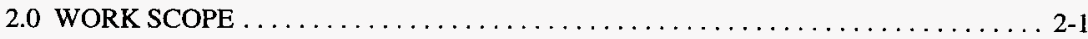

2.1 GENERAL $\ldots \ldots \ldots \ldots \ldots \ldots \ldots \ldots \ldots \ldots \ldots \ldots \ldots \ldots \ldots \ldots \ldots \ldots \ldots \ldots \ldots, 2-1$

2.2 DESIGN BASELINE $\ldots \ldots \ldots \ldots \ldots \ldots \ldots \ldots \ldots \ldots \ldots \ldots \ldots \ldots, 2-2$

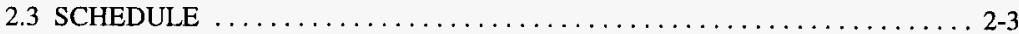

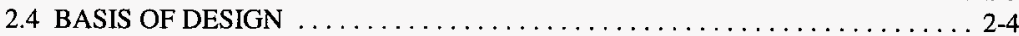

2.5 PRELIMINARY INFORMATION $\ldots \ldots \ldots \ldots \ldots \ldots \ldots \ldots \ldots \ldots \ldots \ldots \ldots \ldots \ldots \ldots, 2-4$

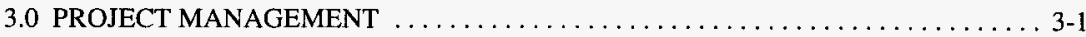

3.1 MANAGEMENT APPROACH $\ldots \ldots \ldots \ldots \ldots \ldots \ldots \ldots \ldots \ldots \ldots \ldots \ldots, 1$

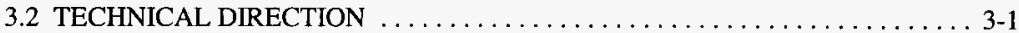

3.3 CD WORK PLAN $\ldots \ldots \ldots \ldots \ldots \ldots \ldots \ldots \ldots \ldots \ldots \ldots \ldots \ldots \ldots \ldots, 1$

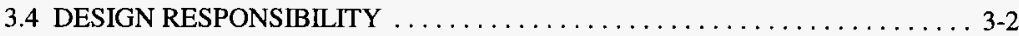

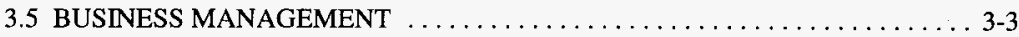

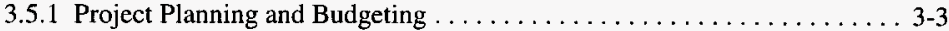

3.5.2 Work Planning and Scheduling $\ldots \ldots \ldots \ldots \ldots \ldots \ldots \ldots \ldots \ldots, 3-3$

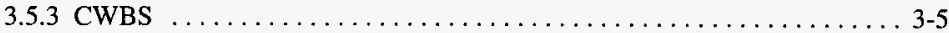

3.5.4 Work Authorization and Funds Control $\ldots \ldots \ldots \ldots \ldots \ldots \ldots \ldots . . \ldots \ldots$

3.5.5 Performance Measurement and Reporting ................. 3-6

3.5.6 Management Reports, Meetings, and Reviews ............... 3-6

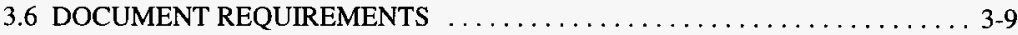

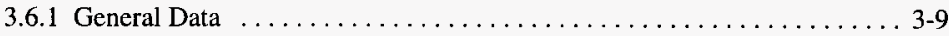

3.6.2 Document Control . ............................. 3-9

3.6.3 Document Identification and Format $\ldots \ldots \ldots \ldots \ldots \ldots \ldots \ldots \ldots, 3-10$

3.6.4 Document Approval ............................. 3-10

3.6.5 Document Transmittal ............................ 3-10

3.6.6 Record Files .............................. 3-11

3.7 RECORDS MANAGEMENT PROCEDURES $\ldots \ldots \ldots \ldots \ldots \ldots \ldots \ldots, 3-11$

3.8 SYSTEMS ENGINEERING MANAGEMENT $\ldots \ldots \ldots \ldots \ldots \ldots \ldots \ldots . . \ldots \ldots \ldots$

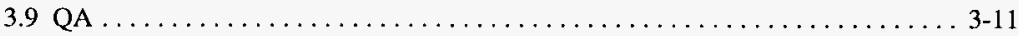

4.0 DESCRIPTION OF REQUIRED SERVICES $\ldots \ldots \ldots \ldots \ldots \ldots \ldots \ldots \ldots \ldots, 4-1$

4.1 DESIGN OBJECTIVES $\ldots \ldots \ldots \ldots \ldots \ldots \ldots \ldots \ldots \ldots \ldots \ldots \ldots, 4-1$ 


\section{HNF-SD-W464-SOW-001}

Revision 0

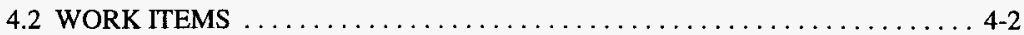

4.2.1 Design End Items $\ldots \ldots \ldots \ldots \ldots \ldots \ldots \ldots \ldots \ldots \ldots \ldots \ldots \ldots \ldots \ldots$

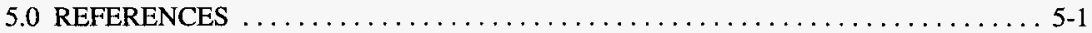

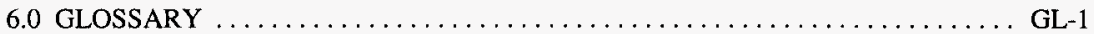


HNF-SD-W464-SOW-001

Revision 0

\section{LIST OF FIGURES}

1-1 Hanford Site 200 East Area and Canister Storage Building Location . . . . . . . . 1-5

1-2 Spent Nuclear Fuel Canister Storage Building Summary Schedule . . . . . . . . . . . 1-9

\section{LIST OF TABLES}

1-1 Tank Waste Remediation System Program Schedule $\ldots \ldots \ldots \ldots \ldots \ldots \ldots \ldots \ldots$

2-1 Proposed Conceptual Design Milestone Schedule $\ldots \ldots \ldots \ldots \ldots \ldots \ldots \ldots \ldots \ldots$ 2-3

3-1 Project Summary Work Breakdown Structure $\ldots \ldots \ldots \ldots \ldots \ldots \ldots \ldots \ldots \ldots \ldots$

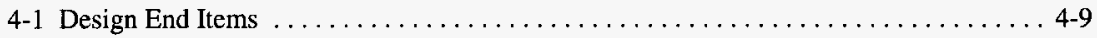


HNF-SD-W464-SOW-001

Revision 0

This page intentionally left blank. 
HNF-SD-W464-SOW-001

Revision 0

\section{STATEMENT OF WORK FOR \\ CONCEPTUAL DESIGN OF SOLIDIFIED HIGH-LEVEL WASTE INTERIM STORAGE SYSTEM PROJECT (PHASE I)}

\subsection{INTRODUCTION}

\subsection{REQUESTED SERVICES}

This Statement of Work (SOW) describes the work scope to be performed by Fluor Daniel Northwest, Inc. as primary contractor (hereafter referred to as the Architect-Engineer [A-E]) under the direction of Lockheed Martin Hanford Company, hereafter referred to as the Buyer. Specifically, the A-E shall prepare a conceptual design (CD) for the Solidified High-Level Waste (HLW) Interim Storage System.

The CD work scope covers the initial design phase of the Solidified HLW Interim Storage and Onsite Transportation System (Project W-464, Phase I Solidified High-Level Waste Interim Storage Project), hereafter referred to as the Project. This initial design phase entails services for $\mathrm{CD}$ development and issuance of the conceptual design report (CDR) for the Solidified HLW Interim Storage and Onsite Transportation System. A large fraction of the CD effort will encompass definition of new installations and retrofit modifications to an existing radioactive material storage facility, hereafter referred to as the Spent Nuclear Fuel (SNF) Canister Storage Building (CSB). The SNF Project is erecting and outfitting the CSB for storage of SNF stored in the Hanford Site K Basin pools. This will include construction of an operations annex, receipt/transfer service bay (load-in/load-out area), three storage vaults each containing 220 storage tubes (six larger tubes for product canister overpack), an adjunct facility to remove gas and liquid from the spent fuel containers (the Hot Conditioning System [HCS] Annex), and a transportation and handling system capable of providing service to all the aforementioned building space. The SNF Project will outfit one vault (Vault 1) with carbon steel storage tubes

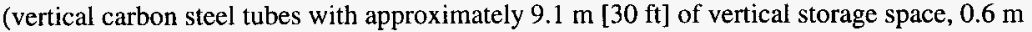
[2 ft] in diameter), inlet/outlet stacks, monitoring/control equipment, and tube plugs and supporting equipment/system.

The HLW Interim Storage System Project intends to use Vaults 2 and 3 for HLW product storage. This will require installation of new, or retrofit, receipt/transfer/handling systems; addition of storage tubes and tube plugs, impact limiters, inlet/outlet stacks, and monitoring/control system equipment; and retrofit of the HCS Annex to provide HLW container overpack capability. Vault 1 of the SNF CSB will contain SNF in passive interim storage during the CSB installation/retrofit activities.

In parallel to the Solidified HLW Interim Storage System CD development, a Tank Waste Remediation System (TWRS) Phase I privatization activity, contracted separately by the U.S. Department of Energy (DOE), is in progress. Input (such as immobilized HLW product and cesium container configuration and waste form physical and radiological characteristics) from 
this activity will be incorporated into the CD of the Solidified HLW Interim Storage System as appropriate. As part of the CD effort, the A-E may be required to support technical interface information development activities between the Project and the Phase I privatization contractors.

\subsection{BACKGROUND}

The mission of the TWRS is to store, treat, and immobilize highly radioactive waste in an environmentally safe, sound, and cost-effective manner. The DOE established the TWRS Program to manage the underground waste storage tanks at the Hanford Site. The TWRS Program includes all activities related to management, retrieval, processing, and disposal of all existing wastes in the tanks and new wastes introduced into the tanks.

In July 1995, the DOE embarked upon a course to acquire Hanford Site tank waste treatment and immobilization services using privatized facilities. Privatization is defined as vendors, under contract with the DOE, using private funding to design, permit, construct, operate, decontaminate, and decommission their own equipment and facilities to treat tank waste (RL 1996). Privatization is divided into two phases. The first phase, termed the "proof of concept" or Phase I, began with award of contract in 1996 and will operate through at least 2007 while treating approximately $6 \%$ to $13 \%$ of the tank waste. Phase I will establish and demonstrate the technical, commercial, and procurement capabilities necessary to privatize Hanford Site tank waste treatment and immobilization. Phase II, which begins with the award of a second contract, will treat and immobilize the remainder of the tank waste.

The privatization contractor(s) will manage the Hanford Site tank waste transferred by the DOE to their custody; retrieve (in Phase I) and transfer this waste for processing; immobilize the waste; and prepare the resultant solidified waste for return to the DOE (ensured to be represented by the Project Hanford Management Contractor [PHMC]). The PHMC will receive sealed canisters of immobilized HLW and transuranic waste for interim storage until they can be shipped offsite for permanent disposal, or sent to a treatment facility for further processing. In Phase I, the PHMC could also receive solidified cesium as an intermediate product from the treatment of tank waste supernate and other non-routine HLW materials. During Phase $\Pi$, the products that will require interim storage are immobilized HLW and potentially immobilized transuranic waste. Dispositioned cesium and strontium capsules may also require interim storage during Phase II pending a programmatic decision on whether to vitrify or overpack this material. Details of the TWRS Program schedule are shown in Table 1-1.

In accordance with the solicitation of Phase I services, transportation, interim storage, and disposal of various products from the demonstration plants (e.g., immobilized HLW, immobilized low-activity waste, separated cesium, etc.) are to be provided by the DOE. Therefore, a facility for solidified HLW interim storage must be provided until the solidified HLW can be transferred to a federal geologic repository for disposal. Phase I solidified HLW interim storage will entail retrofit modification of the SNF CSB to render the CSB suitable for a solidified HLW interim storage mission (Calmus 1996a). 
Table 1-1. Tank Waste Remediation System Program Schedule.

\begin{tabular}{|c|c|c|}
\hline Activity & From & To \\
\hline \multicolumn{3}{|c|}{ Phase I Proof-of-Concept Demonstration } \\
\hline Minimum order quantity operations & June 1,2002 & June 1,2007 \\
\hline Extension operations & $\begin{array}{c}\text { Completion of minimum } \\
\text { order quantity }\end{array}$ & June $1,2011^{*}$ \\
\hline \multicolumn{3}{|c|}{ Phase II Full-Scale Production } \\
\hline Award contract & 2005 & - \\
\hline Design, permitting/licensing, construction & 2005 & 2013 \\
\hline Operations & 2013 & 2028 \\
\hline Decontamination and decommissioning & 2028 & 2033 \\
\hline \multicolumn{3}{|c|}{ Canister Storage Building } \\
\hline Detailed design & October 1999 & October 2000 \\
\hline Construction & October 2000 & September 2001 \\
\hline Receipt of Phase I product & June 2002 & June $2007 / 2011^{\circ}$ \\
\hline Load-out to repository & 2035 & 2040 \\
\hline Decontamination and decommissioning & 2040 & -- \\
\hline
\end{tabular}

"Optional extension period.

\subsection{PROJECT OBJECTIVES}

The CSB is under construction as part of the SNF Project (Project 97A-EWW-379). After SNF CSB construction is finished (scheduled for completion in October 1997), the Storage and Disposal Program intends to modify the CSB. The Project objective is to perform retrofit modifications and install new features (systems, structures, and components) in the remaining vault storage locations to allow the SNF CSB to provide safe, economic, environmentally sound receipt and storage of solidified, immobilized HLW until it can be transferred offsite to a federal geologic repository for disposal or onsite to a treatment facility for further processing (i.e., the solidified cesium product will be returned to the Phase II HLW vendor facility). An additional Project objective is to include a transportation system for transport of solidified HLW products (immobilized HLW canisters, non-routine HLW, and separated cesium containers) from the privatized demonstration plants to the CSB. Solidified HLW interim storage is scheduled to begin in June 2002.

A primary Project objective specific to the $\mathrm{CD}$ activity is to capitalize on existing and readily available SNF CSB Project design, cost, and schedule data to provide a baseline for development of Project cost and schedule estimates. It is expected that the SNF CSB Project information will be particularly useful for those analogous systems which will be procured using performance specifications and fixed-price design and fabricate contracting methods. The SNF CSB and transportation information may provide a significant source from which Project 
baseline cost and schedule estimates can be developed at a minimum cost. Much of the SNF cost estimates and schedules are based on detailed facility/system designs and are confirmed by fixedprice competitive bid. To the extent practical, the Project will use parametric estimating techniques that incorporate SNF Project data resources to develop Project cost and schedule estimates. Estimating techniques and the SNF data input shall be fully documented in the CDR. For facility/system designs which require significant change from the SNF design or are new installations unique to solidified HLW interim storage or transportation, conventional material takeoffs and vendor quotes shall be used as the basis for cost/schedule estimates.

Another primary Project objective specific to the CD activity is to fully use an A-E familiar with Hanford Site procedures and documentation requirements applicable to nuclear-related work, the Hanford Site, the SNF CSB design, and HLW interim storage mission, and, more specifically, preconceptual CSB design studies performed to identify key equipment and modifications necessary to satisfy Project objectives.

\subsection{EXISTING FACILITY AND PROCESS DESCRIPTION (SNF CSB SUB-PROJECT)}

The SNF CSB is located within the 200 East Area of the Hanford Site, approximately $48 \mathrm{~km}(30 \mathrm{mi})$ northwest of Richland, Washington. Figure 1-1 illustrates the general location of the 200 East Area relative to the Hanford Site as well as the SNF CSB location relative to the 200 East Area. The SNF CSB sub-Project includes transportation of the SNF multi-canister overpacks (MCO) to the CSB and design, construction, startup, and operation of the CSB. Complete facility and process descriptions, as well as technical, safety, and other pertinent CSB issues, are thoroughly presented in WHC-SD-SNF-RPT-005, Canister Storage Building Safety Analysis Report - Phase 3 (WHC 1996) (referred to as the SNF preliminary safety analysis report [PSAR]). In addition, the SNF PSAR describes the changes made to the original CSB designed for HLW interim storage under the discontinued Hanford Waste Vitrification Plant (HWVP) Project. This section presents selected excerpts from the SNF PSAR to summarize the SNF CSB facility/equipment and process description. In some cases, editorial license has been invoked to provide the summary. It is expected that the A-E staff is thoroughly cognizant of this information or will review the SNF PSAR, in conjunction with the detailed drawings located in the SNF Project files, to obtain a thorough understanding of the existing facility, process operations, various issues, safety systems, etc. (also see Section 2.5 ).

The SNF MCOs will be shipped from the Cold Vacuum Drying System to the CSB inside a specially designed cask in a sealed configuration (with no active pressure relief mechanism).

The SNF CSB consists of a load-in load-out area, three equally sized below-grade concrete vaults covered by a concrete operating deck, and the HCS Annex. The dimensions of the floor plan encompassing these areas are approximately 70 by $42 \mathrm{~m} \mathrm{(230} \mathrm{by} 137 \mathrm{ft}$ ). Support functions and equipment are housed in the support building located at the north side of the operations building. The support building services are housed in a $15-\mathrm{m}(49-\mathrm{ft})$ wide by $37-\mathrm{m}(121-\mathrm{ft})$ long by $9-\mathrm{m}(30-\mathrm{ft})$ tall metal building. 


\section{Revision 0}

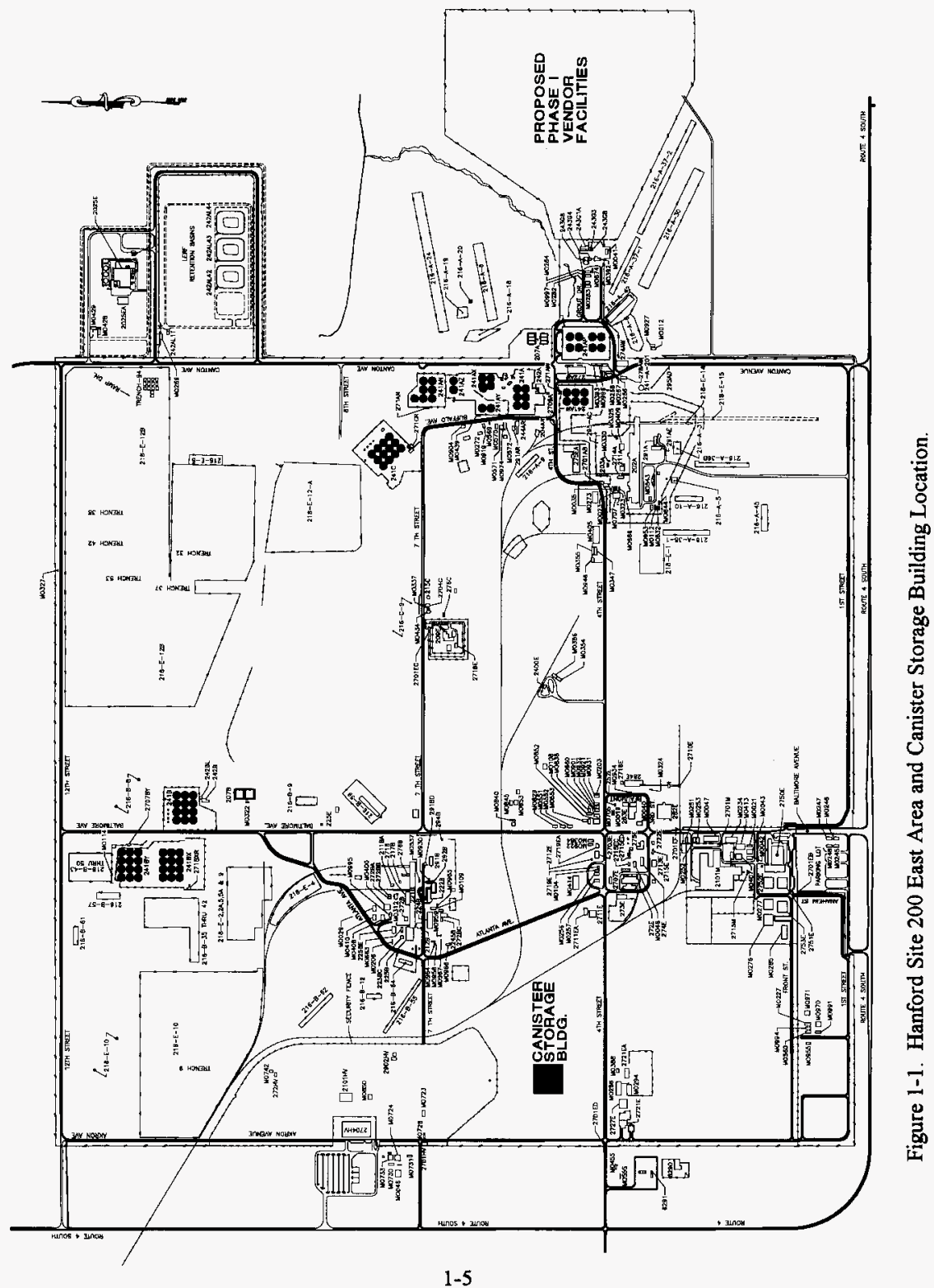


The MCOs are received into a trailer vestibule on the side of the CSB where the transport cask is unlatched from the trailer. A gantry-type receiving crane transfers the casks from the transporter trailer to a below-grade service station pit in the load-in/load-out area located at the north end of the operating area. A second larger and deeper pit is being designed to handle "other" SNF (non-K Basin SNF). In the primary service pit the MCO is reinerted and prepared for sealed staging. Reinerting consists of removal of all gases in the $\mathrm{MCO}$ and refilling the MCO with inerting gas. A service station portable ventilation enclosure provides secondary confinement during the reinerting process. Once reinerting operations are completed the $\mathrm{MCO}$ is removed from the service pit and placed in one of the Vault 1 storage tubes by the multi-canister overpack handling machine (MHM).

The MHM contains an onboard filtered ventilation system that provides confinement and thereby mitigates against the effects of an accidental drop of an MCO during placement in a storage tube. Maintenance of an inerted gas atmosphere surrounding the MCO during transport from the service station to the storage tube will be ensured by the inert gas system on the MHM. During staging of the MCOs, the storage tube is pressurized with inerting gas by the tube vent and purge carts to a slightly positive pressure. The $\mathrm{MCO}$ is not vented during staging and has an active pressure relief valve set at less than $1.0 \mathrm{Mpa}$ gauge $\left(150 \mathrm{lb} / \mathrm{in}^{2}\right.$ gauge $)$ and a $1.0 \mathrm{Mpa}$ gauge $\left(150 \mathrm{lb} / \mathrm{in}^{2}\right.$ gauge) rupture disk to prevent pressure from exceeding the MCO design pressure. During storage, the $\mathrm{MCO}$ will have only the rupture disk for pressure relief.

At the end of staging, the MHM transports the MCO to the HCS Annex for hot conditioning. Before the MHM can remove the plug and pick up the MCO, the tube plug, which is locked down, must be manually unlocked by removing the tube plug bolts. Before the bolts are removed, the pressure gauge in the tube plug is examined to ensure that an MCO rupture disk has not failed and pressurized the tube. The process cart lines are attached to the tube plug monitoring ports, and the pressure tube is evacuated. This evacuation will cause any MCO with pressure near 1.0 Mpa gauge ( $150 \mathrm{lb} / \mathrm{in}^{2}$ gauge) to relieve. The hot conditioning process removes water, hydrates, and hydrides in the fuel to preclude overpressurization of the MCO. The MCOs will be sealed at the HCS Annex before they are placed in Vault 1 storage tubes by the MHM.

Only the northernmost vault (Vault 1 ) is equipped with steel tubes to store the MCOs. Each vault is approximately $50 \mathrm{~m}(164 \mathrm{ft})$ wide by $55 \mathrm{~m}(180 \mathrm{ft})$ long by $14 \mathrm{~m}(46 \mathrm{ft})$ deep and contains 220 carbon steel storage tubes with approximately $9-\mathrm{m}$ ( $30-\mathrm{ft}$ ) long by $0.7-\mathrm{m}$ ( 2 -ft 3 -in.) diameter storage space. In addition, each vault includes six larger-diameter storage tubes to accommodate overpacked MCOs or overpacked HLW containers. The storage tubes are supported from the foundation base slab of the vault and accessed through tube plugs in the concrete reinforced operating deck. The operating deck is approximately $1.5 \mathrm{~m}(5 \mathrm{ft})$ thick. The tube plugs provide shielding, confinement, and process connections. The operating deck and other operations areas, including the load-in/load-out area and the HCS Annex, will be enclosed in a steel building. The steel building is approximately $41 \mathrm{~m}(135 \mathrm{ft})$ wide by $62 \mathrm{~m}(203 \mathrm{ft})$ long by $17 \mathrm{~m}(56 \mathrm{ft})$ tall.

The MCO vault (Vault 1 ) is cooled by natural convection through a dedicated inlet structure, exhaust stack, and plenums. This entails a process whereby cooling air is drawn 
through an inlet duct into a plenum which feeds a vault, flows across the outer surface of the storage tubes, and exits through an elevated exhaust stack that serves the vault. Natural convection is the motive force for drawing cooling air through the vault. The natural convection is caused by a density difference between hot air inside the vault and stack relative to cool intake air. Inlet and exhaust stacks are not provided in Vaults 2 and 3.

The HCS Annex is an extension to the south of the operation deck. It is a reinforced concrete structure that houses process module mounting plates and seven process pits for HCS equipment. The dimensions of the HCS Annex are $10.7 \mathrm{~m}$ (35 ft $3 \mathrm{in}$.) by $42.3 \mathrm{~m}$ (138 $\mathrm{ft} 11 \mathrm{in}$.)

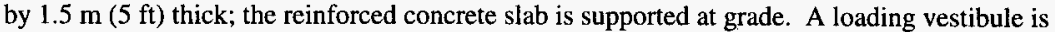
located on the west side of the HCS Annex for egress and ingress of HCS equipment. The dimensions of the loading-staging vestibule are $7.6 \mathrm{~m}$ ( $24 \mathrm{ft} 11$ in.) by $8.3 \mathrm{~m} \mathrm{(27} \mathrm{ft} 4 \mathrm{in}$.). An outer door in the loading-staging vestibule serves as an airlock for area ventilation.

The hot conditioning process is designed to react all bound water, hydrides, and hydrates in the SNF and remove hydrogen, oxygen and any unbound water from the MCO. The process also is designed to passivate the dehydrated fuel by oxidizing it with a premixed oxygen-inert gas mixture to preclude fuel ignition and hydrogen detonation.

Hot conditioning will take place in ovens that are located in six process pits below the HCS Annex operating deck. Confinement is provided by the ovens, which are essentially thermos bottles with a cover ring that allows hot air to be blown through the annular space between the MCO and the interior wall of the oven. The process pit covers serve as secondary confinement and radiation shields. The covers are designed as two parts (plug with a cover) to allow the MHM to move the MCO, while maintaining the double confinement of the SNF, using the same procedure as is used in the rest of the CSB.

Other systems in the HCS Annex that are similar to those in the CSB Vault 1 are the impact absorber at the bottom of each pit, which could prevent catastrophic failure of an MCO if it were dropped to the bottom of the pit, and the MHM guidance system and interlocks, which prevent the MHM from colliding with or damaging the process enclosure of the MCO. Process lines that connect the oven with the process equipment (air cleaning, inert gas purge system, heaters, and fans) run below floor level in a trench to provide shielding from any potential particulate or condensed volatile radioactive materials in the lines. The exhaust will pass through air-cleaning equipment before being discharged from the facility through a stack. A portable process enclosure will be provided for shielding, for making and breaking MCO connections remotely, and for changing air-cleaning traps and filters. The enclosure will be ventilated so that it provides secondary confinement while the MCO's top is exposed and while the MCO's ports are manipulated. The final closure of the $\mathrm{MCO}$ will be made by welding a cover piece on the MCO while the MCO is in the oven after hot conditioning has been completed.

The safety support functions of the CSB are provided by backup electrical power and fire protection and monitoring systems. The design of the CSB does not include a wet-pipe sprinkler system based on the absence of significant existing combustible loading, the control of transient 
combustible loading, the minimum benefit of a sprinkler system, and the reduced potential for moisture entering the storage tube and possibly overpressurizing the storage tube.

The summary SNF CSB Project schedule is provided in Figure 1-2.

\subsection{MAJOR CSB SUBSYSTEMS AND POTENTIAL MODIFICATIONS FOR HLW INTERIM STORAGE AND TRANSPORTATION}

The A-E shall be fully aware of the SNF transportation system and SNF CSB design as well as Project requirements to perform the Project $\mathrm{CD}$ and prepare the Project $\mathrm{CDR}$. The combination of the SNF Project drawings and specifications and PSAR (available in SNF Project files), Project design requirements document (DRD) (Calmus 1996b), preconceptual design studies (prepared by Fluor Daniel, Inc.), and Project preliminary safety analysis and permitting documents (prepared by Westinghouse Hanford Company) are expected to provide a sufficient basis to identify, evaluate, and cost primary transportation and CSB features (facility and subsystems) necessary to satisfy the Project objectives (see Section 1.3) including performance of the $\mathrm{CD}$ and completion of the CDR.

\section{SNF Project CSB Modifications to Original HWVP CSB Design}

The CSB was originally designed to interim store immobilized HLW canisters generated from the HWVP. Conversion of the CSB from the HWVP Project mission to the SNF Project mission has resulted in fundamental changes to many of the HWVP CSB facility and subsystems. The major CSB facility and subsystem changes resulting from the CSB mission change include, but are not limited to, the following:

- Method of transportation of HLW products (truck versus shielded canister transporter)

- Removal of intake plenum shielding louvers in all three vaults

- Deletion of insulating concrete in Vault 1

- Modification of insulating concrete design in Vaults 2 and 3 to accommodate the SNF Project schedule

- Extension of below-grade walls to isolate the individual vaults thereby creating individual intake and exhaust plenums for each vault (resulting in modified natural convection characteristics)

- Use of integrated gantry cranes and shielded handling system (MHM) versus a shielded canister transporter to transport storage products throughout the facility 


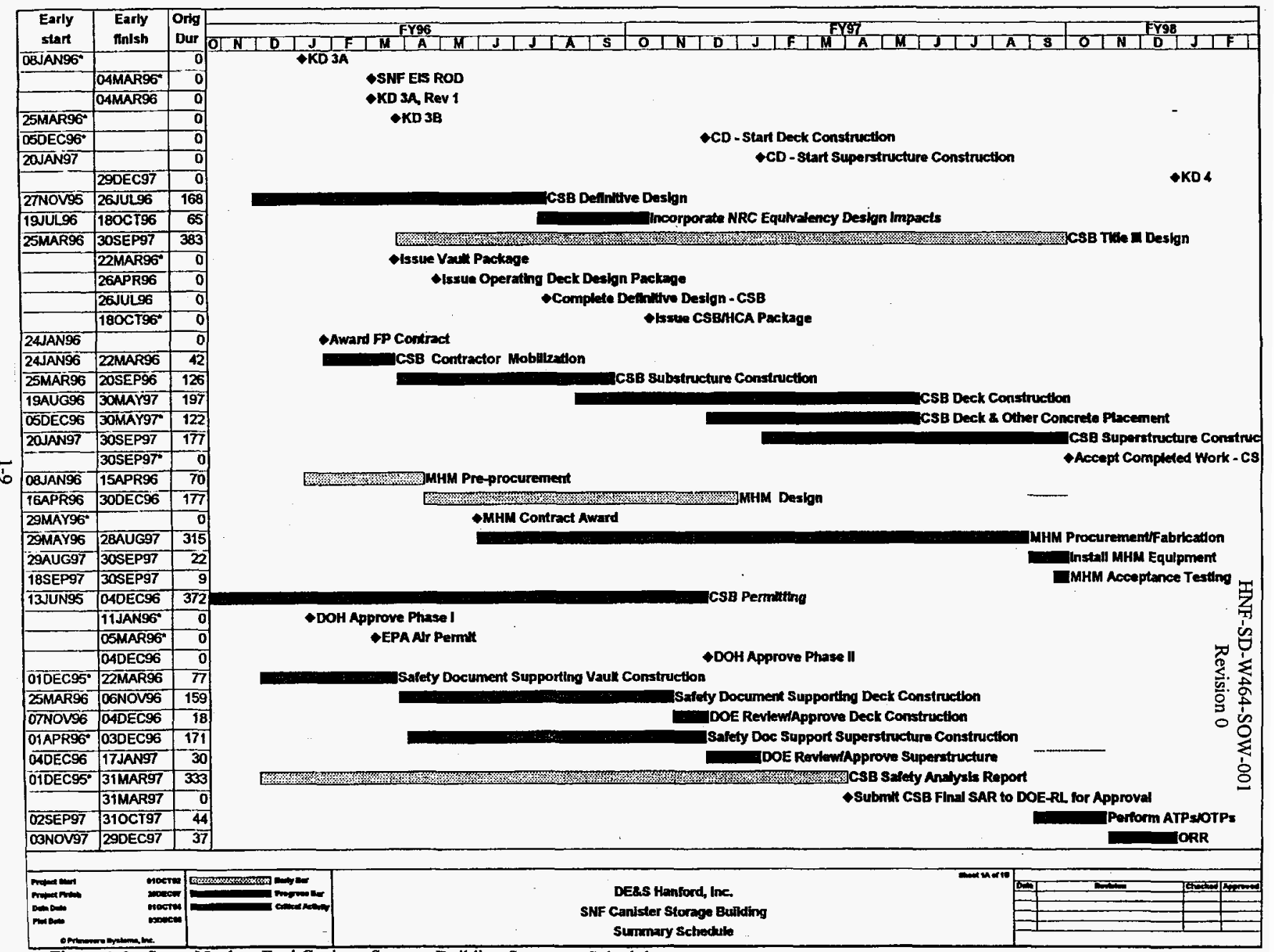

Figure 1-2. Spent Nuclear Fuel Canister Storage Building Summary Schedule. 
- Increased number of Safety Class I structures, systems, and components associated with maintaining confinement in the MCOs

- Modification to intake and exhaust bases of the operating deck structure to meet natural phenomenon threats (tornado wind loads)

- Addition of primary receiving/transfer pit and larger secondary pit in the loadin/load-out area

- Reduction of tube embed diameters

- Addition of HCS Annex and extension of MHM capability to service the Annex

- $\quad$ Reduction of operating services (e.g., office space and supporting functions)

- $\quad$ Addition of security systems to accommodate SNF.

\section{Project Design Requirements}

New design requirements were developed for the Project to support the Phase I privatization HLW Interim Storage mission. The Project design requirements are provided in the DRD (Calmus 1996b). The Project design requirements have changed from those required for the HWVP mission, and the primary changes are as follows:

- New immobilized HLW composition and canister configuration--The new Phase I composition and canister configuration (RL 1996) impacts requirements associated with canister transportation, vault and tube cooling, shielding, and canister receipt/transfer/handling/overpack.

- Addition of separated cesium product to HLW interim storage mission--The separated cesium product is to be a free-flowing powder (versus glass product to be stored under the mission of the HWVP Project) and possesses different chemical, radionuclide, and canister configuration than the immobilized HLW product and canisters. Addition of the separated cesium product impacts requirements associated with product transportation, vault and tube cooling, shielding, and canister receipt/transfer/handling/overpack.

- $\quad$ Solidified HLW product temperature (heat load) control--Because of the SNF Project design modification to Vaults 2 and 3, which includes changes to vault configuration (three separate below-grade vaults versus one in the HWVP CSB design), intake/exhaust stack plenum design, and changes to Phase I HLW product maximum heat loads and heat load distribution, the vault cooling characteristics have undoubtedly been altered from the HWVP design. This change (from HWVP design) may result in the need to perform appropriate thermal analyses (e.g., natural convection modeling) to provide confidence that the new design of the SNF CSB 
Vault 2 and 3 satisfies solidified HLW temperature requirements. If the vaults do not provide sufficient cooling, new features may need to be added to the CSB design for Vaults 2 and 3.

\section{Preconceptual Engineering Studies}

Preconceptual engineering studies (see Section 2.5) were performed to determine the feasibility of outfitting/retrofitting the SNF CSB for interim storage of Phase I solidified HLW products. Key subsystems were identified which would require retrofit of existing SNF subsystems. These subsystems were evaluated to determine the degree of retrofit and roughorder-of-magnitude (ROM) cost to provide features to accommodate the Project mission. In addition, transportation and CSB features unique to solidified HLW interim storage requiring new subsystems were identified and evaluated. These studies should provide the basis for prioritizing $\mathrm{CD}$ activities relative to identification, analysis, and cost/schedule estimating of key subsystems additions or retrofits.

\section{Project Schedule}

The HLW Interim Storage System Project planning indicates that the CSB facility/transportation system CD will be completed by January 1998, detailed design will be completed by September 2000 , and facility startup will begin by June 2002 . The SNF Project is scheduled to be completed (SNF MCOs loaded in Vault 1) by December 1999.

\subsection{HLW INTERIM STORAGE PROCESS DESCRIPTION}

The transportation, receiving, unloading, material handling, and storage operations associated with solidified HLW product canisters (immobilized HLW canisters and separated cesium containers) are similar to but somewhat simpler than those for SNF. The generation of explosive mixtures of hydrogen is not considered an issue with HLW and cesium containers. Consequently it is not necessary to sample and purge the incoming shipments or the stored tubes or condition the solidified HLW product canisters. The CSB receiving area, service station, and MHM can most likely be adapted to receiving and handling the solidified HLW product canisters. The HCS Annex welder may be adaptable for sealing solidified HLW product canisters in overpack containers. Preliminary operation steps, sequence, and time-cycle estimates, as well as study assumptions, and discussion of operational steps were developed as part of Project preconceptual engineering studies (see Section 2.5). The process information provided in the referenced engineering study should provide a preliminary basis from which more detailed process descriptions can be developed by the A-E, as necessary for the CD.

\subsection{DESIGN INTEGRATION}

The CD work scope described in this SOW requires a strong interface with other Hanford Site programs and activities. To achieve an effective integration of all Project participants 


\section{HNF-SD-W464-SOW-001}

Revision 0

(including Buyer and U.S. Department of Energy, Richland Operations Office [RL] personnel), key A-E personnel and a significant majority of their technical staff shall be located in the TriCities, Washington. This arrangement will facilitate the total Project team integration and allow efficient input of technical information during the $\mathrm{CD}$ effort. Key A-E management personnel and some technical staff are expected to have sufficient working experience at the Hanford Site and with the SNF CSB Project and be identified in the CD work plan. 


\title{
HNF-SD-W464-SOW-001
}

\author{
Revision 0
}

\subsection{WORK SCOPE}

The A-E shall be fully responsible and accountable for the work performed under this SOW. This work scope demands professional quality, safety, technical accuracy, and costeffectiveness in coordination and development of all CD media (modified drawings [SNF Project drawings], sketches, figures, etc.), cost estimates, schedules, technical reports, calculations, and other CD services provided by the A-E. All design services and technical work required to produce acceptable design media shall meet quality standards and comply with all applicable criteria, such as federal and state regulations, industry standards, and the Buyer's requirement documents (see Section 2.5)

\subsection{GENERAL}

The A-E shall perform the CD in a manner consistent with the Project objectives (see Section 1.3), technical scope, budget, and schedule identified in this section and in Section 4.0. The CD shall be developed in sufficient detail to establish the overall Project scope, design features, and concepts such as: process; mechanical; electrical; heating, ventilating, and airconditioning (HVAC); infrastructure interface; instrumentation; control; building vaults configuration and retrofit definitions; supporting system designs; and functional and technical analysis In addition to appropriate basic CD support analyses (such as thermal, structural, seismic, effluent, etc.), the A-E shall also perform necessary special design support analyses including, but not limited to, preliminary failure modes and effect, process hazards, fire hazards, shielding, life-cycle cost, preliminary safety (and safety class) assessments, and operability/ maintainability assessments. If during the course of the $C D$ the A-E identifies design support analysis that were not specifically identified in the work plan (see Section 3.3) and are considered by the Buyer to be part of the A-E's basic design responsibility, a separate SOW or revision to this SOW will be prepared by the Buyer (with input from the A-E) and a new or revised work plan issued with additional funds provided via a Buyer-prepared work order.

The CD work shall be documented and summarized in a CDR. All design media prepared under this contract shall become the property of the DOE. The A-E shall use the following principal objectives to develop the CD for the Project.

- Meet all technical requirements as imposed by the baseline documents (see Section 2.3).

- Provide cost and schedule estimates using, to the extent practical, existing SNF and HLW Interim Storage Project data (see Section 1.3).

- Provide the minimum construction cost consistent with operational, environmental, security, and safety requirements, and with acceptable life-cycle cost analyses. 
- Meet safety, environmental, security, energy, and quality assurance (QA) requirements imposed by the baseline documents.

- Meet all applicable federal, state, and local requirements.

\subsection{DESIGN BASELINE}

Conceptual design encompasses those efforts that develop a project's technical scope, ensure project feasibility and performance levels, develop cost estimates, provide a complete description of the project, and develop design parameters for all engineering disciplines and facility functional descriptions. The A-E shall ensure that new installations and retrofit modifications to SNF CSB systems, structures, and components, which are provided to support the overall Solidified HLW Interim Storage System design, satisfy all the Project baseline design criteria.

This section summarizes the required tasks for $\mathrm{CD}$ for the Project. Details for some special specific tasks to be performed by the A-E are provided in Sections 3.0 and 4.0. The CD efforts shall use SNF design, engineering, and project documents and HLW Interim Storage Project documents to the extent practical and cost-effective.

The Project design baseline will consist of the cost, schedule, and technical baseline for the Project, consistent with program goals. The design baseline, including the CDR, will effectively encompass the Project objectives. The design baseline includes documentation generated and controlled by the HLW Interim Storage System Project and documentation generated as part of the CDR effort. The design baseline is provided to identify where the CDR fits into the Project's baseline. The key design baseline documentation is discussed below.

The HLW Interim Storage System Project-generated documentation is as follows:

\section{- DRD}

- Project master schedule (Level 0 and Level 1 [operations, decontamination, and decommissioning] schedules)

- Budget authorization/budget outlay schedule

- Additional supporting documentation (in accordance with this SOW).

The A-E-generated CDR, including, but not limited to, the following:

- Interface control documents (e.g., functional and physical interfaces)

- Design concepts and architectures (e.g., transportation and CSB systems/facility) 
- Process flow diagrams (e.g., HVAC, natural convection, unit operations)

- Physical/mechanical flow diagrams (e.g., material, unit operations)

- $\quad$ Piping and instrumentation diagrams

- System descriptions

- Total Project cost/schedule estimate

- Life-cycle cost estimate with basis (design, construction, startup)

- QA approach

- Systems engineering approach.

- Permitting plan

- Engineering analysis results (e.g., summary of safety evaluation, shielding evaluation, constructability assessment, natural convection analysis, etc.)

- CD assumptions, bases, issues.

\subsection{SCHEDULE}

The CD efforts for the Solidified HLW Interim Storage System Project are scheduled to begin by January 1997, with CDR completion scheduled for January 1998. The proposed CD milestones are presented in Table 2-1.

Table 2-1. Proposed Conceptual Design Milestone Schedule.

\begin{tabular}{|l|c|}
\hline \multicolumn{1}{|c|}{ Milestone* } & Date \\
\hline $\begin{array}{l}\text { Submit conceptual design work plan (including facilitated kickoff } \\
\text { meeting) }\end{array}$ & $\begin{array}{c}45 \text { days after } \\
\text { authorization to proceed }\end{array}$ \\
\hline Design Review (30\%) & April 30, 1997 \\
\hline Issue draft conceptual design report for review (90\%) & September 30, 1997 \\
\hline Issue approved conceptual design report & January 30,1998 \\
\hline
\end{tabular}

*Completion of scheduled milestones shall be defined as receipt of required documents. 


\subsection{BASIS OF DESIGN}

The CD shall meet the requirements specified in the Project DRD, which will be provided by the Buyer at the start of the CD effort. The DRD may be revised as required by the Buyer in accordance with the Buyer's change control procedures.

\subsection{PRELIMINARY INFORMATION}

The following preliminary list of information items will be made available at the beginning of the CD effort with exceptions as noted.

\section{Criteria documents}

- DRD

- WHC-SD-WM-DRD-012, Design Requirements Document for the Interim Store Phase I Solidified HLW (Calmus 1996b)

- Project summary work breakdown structure (PSWBS)

Information documents

- Preconceptual engineering, safety, and permitting studies

- $\quad$ Canister Storage Building HLW Implementation Study (Fluor 1996a)

- $\quad$ Canister Storage Building HLW Implementation Study Supplemental Report (Fluor 1996b)

- WHC-SD-WM-TI-781, Canister Storage Building Evaluation of Nuclear Safety for Solidified High-Level Waste Transfer and Storage (Kidder 1996)

- $\quad$ Environmental Requirements Checklist for the High-Level Waste Storage Project Canister Storage Building (Deffenbaugh 1996)

- $\quad$ Receipt Acceptance/Work Qualification Strategy (to be provided April 1997)

- Project definition engineering studies

WHC-SD-WM-SP-011, Solidified High-Level Waste Interim Storage Alternative Analysis and Path Forward Recommendation (Calmus 1996c)

- Applicable Buyer policies and procedures 
- SNF CSB design, construction, and as-built drawings; engineering studies; specifications; safety analysis; etc. to the degree they are available from the SNF Project

- $\quad$ SNF CSB Project drawings and specifications and SNF PSAR (WHC 1996) located at the CSB site in Trailer MO-724.

The Buyer shall establish the applicable version of HLW Interim Storage Project documents. The most current version of SNF Project documents shall be used in CD to identify and evaluate major systems/subsystems/facility features; this may necessitate significant subsystem CD updates at appropriate intervals. Any deviation from technical criteria documents (primarily the DRD) will require appropriate Buyer and/or RL approvals in accordance with the Buyer's procedures. 
HNF-SD-W464-SOW-001

Revision 0

This page intentionally left blank. 


\subsection{PROJECT MANAGEMENT}

This section describes the Project management approach and the requirements for the A-E's project management system for the Project CD efforts.

\subsection{MANAGEMENT APPROACH}

The RL is the owner of the SNF CSB and the overall Solidified HLW Interim Storage System Project. The director of the RL Waste Disposal Division will oversee the Project activities for the DOE. The Buyer's Solidified HLW Interim Storage System Project Office, hereafter referred to as the Buyer's Project Office, will provide overall Project management. Administration of the A-E contract will be provided by the designated Buyer's contract specialist assigned by the Buyer's Procurement organization. The overall management approach to the Project shall be consistent with the requirements delineated in DOE Order 430.1, Life-Cycle Asset Management (DOE 1995a).

\subsection{TECHNICAL DIRECTION}

The Buyer's Project Office has the responsibility and authority for technical direction of the A-E activities within the scope of this SOW. Any changes to the requirements of this SOW, or direction that impacts any of the contract cost/schedule provisions or its terms or conditions, must come only from the Buyer's contract specialist or the designated authority. The A-E shall notify the Buyer's contract specialist of any direction it has received from the Buyer's Project Office that impacts the contract provisions and request authorization. The Buyer's Project Office, along with the contract specialist, will ensure that the A-E complies with the requirements of this SOW.

\subsection{WORK PLAN}

The task objectives, approach, activities, deliverables, overall schedule, and resources required to accomplish each specified task shall be presented in the $\mathrm{CD}$ work plan to be prepared by the A-E. The work plan information should be presented in a manner consistent with the contractor work breakdown structure (CWBS). The estimated number and type of CD-modified SNF drawings (H-2 drawings modified to SK-drawings), sketches, specifications, calculations, reports, etc., for each work element shall be provided. This work scope may be modified after discussions between the A-E and the Buyer (see Section 3.5.6.2). Initially it is expected that the work plan shall include, but not be limited to, the following.

- Identify the objective, technical approach, and organizational structure. 
- Describe the technical work scope to be performed for each task including, but not limited to, those listed in Sections 3.0 and 4.0. To the extent possible, describe the level of detail planned for each task, and provide explicit examples, e.g., sketches of similar equipment/systems for similar projects.

- For each task, identify activities to be performed, and list specific documents and types of design drawings/diagrams/schedules and design support analysis to be produced. Include a bar chart schedule with total resources required, including estimated staff hours.

- Define a list of deliverables with a schedule for each task. Highlight all intermediate deliverables, including planned interim review packages, external data needs, etc.

- When necessary for a task, identify key input that must be provided by other Project participants, work task elements, and/or outside entities. Describe the required input and any associated constraints or assumptions for specific activities.

- Include the contract master schedule in accordance with Section 3.5.2.

- Include the time-phased performance measurement baseline (PMB), by CWBS, for the CD effort.

The work plan shall cover all deliverables and $C D$ work scope as defined in the most current version of this SOW, and shall include all applicable items defined in Sections 3.0 and 4.0 of this SOW. The work plan shall be submitted for Buyer review and approval. The A-E shall maintain the approved CD work plan as a controlled document that is updated monthly to reflect approved changes in the $\mathrm{CD}$ work scope and schedule. One set of Buyer comments will be provided for comment disposition by the A-E. Comments will be provided to the A-E within 10 working days upon receipt by the Buyer. The A-E shall maintain the approved CD master schedule as a controlled document that is statused monthly to reflect progress and any approved changes in the CD work scope and schedule, as specified in Table 2-1. Scope and/or schedule changes will require the customer's approval before work initiation by the A-E.

\subsection{DESIGN RESPONSIBILITY}

The A-E shall ensure that new installations and retrofit modification designs to SNF CSB systems, structures, and components, which are provided to support the overall Solidified HLW Interim Storage System design, satisfy the Project design requirements.

The A-E shall be considered the responsible design organization as defined in ANSI/ASME NQA-1-1989, Quality Assurance Program Requirements for Nuclear Facilities, Supplement 3S-1, Section 2 (ANSI/ASME 1989) excluding designs furnished by the Buyer via baseline documents and design media. 


\subsection{BUSINESS MANAGEMENT}

\subsubsection{Project Planning and Budgeting}

The A-E shall provide support and develop information, as requested by the Buyer's Project Office, to support preparation of documentation as required for budget submittals and other planning activities. For work planning it should be assumed that three meetings will be held, with each meeting lasting 2 hours.

\subsubsection{Work Planning and Scheduling}

The A-E shall use the PSWBS, shown in Table 3-1, as the basis for developing its own CWBS. All A-E work planning, budgeting, and scheduling shall be consistent with the management control systems (graded approach) prescribed in DOE Order 430.1, Life-Cycle Asset Management (DOE 1995a) for applicable work breakdown activities. The A-E's work definitions, budgets, schedules, and cost estimates shall be prepared in accordance with the A-E's CWBS.

The A-E shall prepare a contract master schedule that shows the sequence of planned tasks, constraints, and interdependence for major activities and milestones for each required task. This schedule shall be developed in sufficient detail to plan and control the required work tasks. The schedule shall be included in the work plan. The contract master schedule shall:

- Be time-phased, resource-loaded, and logic-based for all CD tasks by CWBS

- Support and roll up to the Project master schedule

- Indicate established CD critical deliverables (as specified in Table 2-1)

- Be updated monthly to reflect progress and agreed-upon changes.

For each scheduled critical deliverable, the A-E shall prepare a deliverable description sheet that defines the acceptable deliverable product or work to be accomplished. The A-E shall generate a schedule deliverable status log with appropriate identification detail, including schedule, and actual and forecast dates for each deliverable. This log shall be statused and updated as part of the monthly review meetings. 
HNF-SD-W464-SOW-001

Revision 0

Table 3-1. Project Summary Work Breakdown Structure. (2 sheets)

\begin{tabular}{|c|c|}
\hline Code number & Title \\
\hline 1 & Hanford Site \\
\hline 1.1 & TWRS Mission \\
\hline 1.1 .1 & TWRS Program \\
\hline 1.1.1.3 & Waste Disposal \\
\hline 1.1.1.3.04 & Storage and Disposal \\
\hline 1.1.1.3.04.02 & Interim Storage \\
\hline 1.1.1.3.04.02.01 & Project Administration \\
\hline 1.1.1.3.04.02.01.01 & Current FYWP Maintenance \\
\hline 1.1.1.3.04.02.01.02 & Prepare ADS \\
\hline 1.1.1.3.04.02.01.03 & Prepare MYPP \\
\hline 1.1.1.3.04.02.01.04 & Project Management Support \\
\hline 1.1.1.3.04.02.02 & Systems Definition \\
\hline 1.1.1.3.04.02.02.01 & Engineering Studies/Estimates/Requirements/Recommendation \\
\hline 1.1.1.3.04.02.02.02 & Product Acceptance \\
\hline 1.1.1.3.04.02.02.03 & DRD - Phase II \\
\hline 1.1.1.3.04.02.02.04 & Phase II \\
\hline 1.1.1.3.04.02.02.05 & Project Management Plan \\
\hline 1.1.1.3.04.02.03 & Facilities \\
\hline 1.1 .1 .3 .04 .02 .03 .01 & Project Management \\
\hline 1.1 .1 .3 .04 .02 .03 .02 & Conceptual Design \\
\hline 1.1 .1 .3 .04 .02 .03 .03 & Definitive Design \\
\hline 1.1 .1 .3 .04 .02 .03 .04 & Construction/Startup \\
\hline 1.1.1.3.04.02.04 & Operations \\
\hline 1.1 .1 .3 .04 .02 .04 .01 & Pre-Production Operations \\
\hline 1.1 .1 .3 .04 .02 .04 .02 & Phase I/II Operations \\
\hline 1.1 .1 .3 .04 .02 .04 .03 & Post-Production Operations \\
\hline 1.1 .1 .3 .04 .02 .04 .04 & Deactivation \\
\hline 1.1 .1 .3 .04 .02 .05 & Repository Fees \\
\hline
\end{tabular}


HNF-SD-W464-SOW-001

Revision 0

Table 3-1. Project Summary Work Breakdown Structure. (2 sheets)

\begin{tabular}{|l|l|}
\hline \multicolumn{1}{|c|}{ Code number } & \multicolumn{1}{c|}{ Title } \\
\hline 1.1 .1 .3 .04 .02 .05 .01 & Repository Fees \\
\hline 1.1 .1 .3 .04 .02 .06 & Closure/D\&D \\
\hline 1.1 .1 .3 .04 .02 .06 .01 & Closure/D\&D \\
\hline
\end{tabular}

ADS = Activity data sheet

$\mathrm{D} \& \mathrm{D}=$ Decontamination and decommissioning

DRD = Design requirements document

FYWP $=$ Fiscal year work plan

MYPP $=$ Multiyear program plan

TWRS = Tank Waste Remediation System

\subsubsection{CWBS}

The A-E shall develop a CWBS for review and approval by the Buyer. The CWBS shall identify all work to be accomplished. All planning and performance measurement shall be based on the approved CWBS and include the following requirements.

- Be compatible with and support the PSWBS.

- Provide for a logical CWBS and PSWBS rollup of all budget, earned-value, and cost data.

- Provide a CWBS dictionary description for each element.

\subsubsection{Work Authorization and Funds Control}

Initial work authorization and funding to the A-E shall be via a Task Order. Work authorization and funding obligations for scope changes will be provided by the Buyer's Contract Procurement organization via modifications/revisions to this SOW or the DRD. The A-E must receive specific written approval from the Buyer's contract specialist before proceeding with any new work resulting from technical direction issued by the Buyer's Project Office. However, for expediency, work authorization for approved changes may be provided by the Buyer's contract specialist to the A-E before formal A-E pricing proposal, negotiation, and final work scope modification. 
HNF-SD-W464-SOW-001

Revision 0

\subsubsection{Performance Measurement and Reporting}

A time-phased PMB (staff hours and dollars) for completing CD shall be prepared by the A-E and included in the CD work plan. The PMB shall:

- Be consistent with directed work scope, work plan, and CWBS

- Be structured by CWBS level

- Be maintained through the A-E's change control process and updated as required

- Be consistent with and roll up to the CWBS reporting level baseline at the lowest level

- Be documented to the lowest level of the CWBS, including the earned-value methodology to be used.

The A-E shall submit, and present monthly in accordance with the Buyer's Project Office requirements, cost performance information that provides integrated CWBS cost/schedule data for measuring performance. The buyer will incorporate this information into the PHMC baseline cost/schedule baseline. Earned value progress and any changes in the latest revised estimate shall be included as part of the cost performance information. All the A-E's detailed budget information (staff hours and dollars) below the CWBS level shall be available for review by the Buyer if changed. The cost performance information shall be presented during review meetings (see Section 3.5.6.4) and documented in meeting minutes.

\subsubsection{Management Reports, Meetings, and Reviews}

3.5.6.1 Management Reports. The A-E shall provide monthly activity status reports. These reports shall be submitted during review meetings (see Section 3.5.6.4) and documented in meeting minutes. Activity status information shall include the following:

- Project manager's narrative highlights and status assessment for each CWBS element including activities planned for the next month

- Issues/concerns (cost, schedule, technical), recommended resolution, and progress toward resolution

- Agreements and/or commitments for problem or technical issue resolution

- Staffing status including planned and actual staff.

Variance analysis shall be on the current month and cumulative-to-date, and shall include cause, effect, and corrective action. The variance analysis shall be prepared at the CWBS level 
with explanation lower as required to adequately address problems (offsetting variances, etc.). Variance analysis thresholds (current month and cumulative date) shall be as agreed upon by the Buyer and the A-E through negotiation.

3.5.6.2 Facilitated Kickoff Meeting. A facilitated design kickoff meeting will be held at the A-E's Office after the issuance of a notice to proceed (expected to be 2 to 3 days). The A-E will be responsible for planning the kickoff meeting, providing facilitators, and meeting control. The meeting purpose is to provide the A-E with additional information as required to accomplish the specified CD tasks and to develop a basis for Project partnership. This meeting will focus on a discussion of the $\mathrm{CD}$ work scope and the goal, role, and responsibility of each Project participant. Pertinent documents also will be reviewed and discussed.

3.5.6.3 Issues/Concerns and Action Tracking System. The A-E shall develop and maintain an appropriate issues and concerns tracking logbook, which could significantly impact technical/cost/schedule of major Project activities (CD, detailed design, construction, transportation, etc.). This logbook will be used to record and track significant CD-related issues that are raised by any Project participant or outside oversight entity, but are not immediately resolvable. A planned issue resolution time frame will be defined. A monthly report of open issues/concerns shall be prepared and issued along with, or as part of, the review meeting minutes (see Section 3.5.6.4). A similar logbook for actions, generated through correspondence or meetings, tracking, and closure shall be used during the $\mathrm{CD}$ effort. This action tracking list shall also be statused and issued monthly along with the monthly review meeting minutes.

3.5.6.4 Review Meetings. Bi-weekly meetings shall be held at the A-E's offices to review work progress. These meetings will most likely be changed to monthly meetings (with the Buyer's approval) once $\mathrm{CD}$ activities become more established. During these meetings, the A-E shall present Project technical progress and description, cost, and schedule status for each task.

During the informal presentation, the A-E shall identify existing or anticipated problem areas for each task (including impacts), and report on progress toward problem resolution. The A-E shall issue the meeting agenda 5 working days before the meeting and prepare and distribute the meeting minutes to the Buyer's Project Office within 10 working days after the meeting. Minutes shall emphasize agreements, commitments, and planned actions. The Buyer's representative shall concur with the text of the minutes before they are issued.

3.5.6.5 Design Review Meetings. Design review meetings shall be convened to ensure that the design objectives are being achieved. Design reviews shall be identified in the work plan. For each critical deliverable, at a minimum, two scheduled design reviews (30\% and $90 \%$ ) are to be planned and shall be indicated on the contract master schedule. The first $30 \%$ design review shall be informal in nature; however, the second $90 \%$ design review shall be designated as a formal design review. The Buyer will determine the location of the design reviews, which shall be conducted in accordance with the requirements of the Buyer's Project Office design review process.

The HLW Interim Storage System Project CD will include an informal $30 \%$ design review and a formal $90 \%$ design review. These CD reviews will include a comment/comment- 
disposition process. Definitions of design stage completion and identification of key deliverables are as follows.

\section{$30 \%$ Design}

The design is considered $30 \%$ complete when, at a minimum, the following CD activities are completed:

- Process, materials, and physical process flowsheet are completed to a sufficient level of detail that the basis for the design is established

- Design concepts have been evaluated and a single design concept selected for further development, including sketches in sufficient detail to convey the concept

- A summary is provided of design solution implementation

- Key uncertainties/issues are identified and resolution path forward proposed

- Sufficient detail is provided such that key features of the CD can be well understood

- The design approach for $\mathrm{CD}$ and the detailed design and construction approach should be well understood. Path forward for unresolved issues/approaches is presented and discussed at this point.

The $30 \%$ design review will be performed to satisfy these objectives. The review will be informal in that the $\mathrm{CD}$ work will continue in parallel with the review and the comment disposition process.

\section{0\% Design}

The design is considered $90 \%$ complete when the A-E has completed all design media for $\mathrm{CD}$ and is ready to submit the entire design package to the design agent. Further work on any portion of the package is limited to incorporating design review comments from the design agent's design review. Key deliverables include the following:

- Project validation package input

- CDR

- Cost estimate

- A complete drawing package

- Completed specifications

- All other contractually specified documents and deliverables.

The $90 \%$ design review process will be in accordance with PHMC procedures and will use a Record Comment Review process. 
3.5.6.6 Coordination Meetings. Coordination meetings, including telephone conferences, will be held, as required, between the Buyer and the A-E to discuss various Project issues as they arise. Meeting minutes will be prepared by the A-E and issued to the meeting participants within 3 working days of the meeting for review and comments. Meeting minutes shall be issued within 7 working days of the meeting. The Buyer's Project Office shall concur with the text of the minutes before they are issued.

3.5.6.7 Communications. Any oral communications, including telephone conferences, having an impact on the work shall be confirmed in writing by the A-E within 5 working days. These communications records shall be issued with a controlled record number and maintained as retrievable records.

\subsection{DOCUMENT REQUIREMENTS}

Record documents will be generated during the course of the design. Record documents are those end-item documents required by this SOW.

\subsubsection{General Data}

In almost all cases where drawings are to be used to convey information in the $\mathrm{CD}$, the drawings will be modified SNF CSB Project detailed design drawings. The A-E shall retain SNF drawing information and clearly delineate changes made to convey information for the HLW interim storage $\mathrm{CD}$. For projects involving retrofit of an existing building and systems, sketches are most generally used to convey information in the CD effort; therefore, it is expected that most information will be provided in sketches. For hand-drawn and more formal drawings (e.g., for complex systems where the A-E has determined computer-aided design and drafting drawings are necessary), a systematic identification system and description format will be used for reference.

Full-size drawings (most likely original or modified SNF Project drawings) shall be 71 by $102 \mathrm{~cm}$ ( 28 by 40 in.). Reduced drawings can be 36 by $50 \mathrm{~cm}$ ( 14 by 20 in.) if mutually agreed upon by the Buyer and the A-E. Informal drawings or sketches included in topical reports can be 28 by $21.6 \mathrm{~cm}$ ( 11 by 8.5 in.) or 28 by $43 \mathrm{~cm}$ (11 by 17 in.). Drawing sizes other than those listed may be accepted on a mutually agreed upon basis. All drawings and sketches shall be furnished by the A-E pending approval by the Buyer.

\subsubsection{Document Control}

Preparation, identification, approval, transmittal, and final disposition of new and revised record documents shall conform to the A-E's established procedures or special instructions. Use of contract documents shall be controlled in accordance with the A-E's established procedures or 
special instructions. The A-E shall submit its document control guidance or procedures to the Buyer's Project Office for review.

\subsubsection{Document Identification and Format}

3.6.3.1 Numbering System. The A-E shall use a unique numbering system for all SNF documents used in the $\mathrm{CD}$ effort and also include sketches, correspondence, technical reports, specifications, etc. The A-E shall comply with all Hanford Site criteria relative to document practices regarding document/design media (e.g., modified SNF H-2 drawings, sketches, deliverable documents, topical reports, etc.), format, identification, and numbering. The identification and numbering system used by the A-E will be provided to the Buyer for review and concurrence.

3.6.3.2 Drawings. The A-E will provide drawing and/or sketch numbers. A drawing traceability list shall be included near the title block to provide an auditable trail forward and backward between existing and revised drawings. Drawings shall contain a revision block that includes, at a minimum, a revision number, revision date, revision description, and revision approval initials. Each drawing shall include a list of interfacing drawings or sketches.

\subsubsection{Document Approval}

All design drawings, sketches, and technical documents submitted to the Buyer's Project Office for review shall first be thoroughly reviewed by appropriate members of the A-E's technical staff including, but not limited to, QA, safety, and drafting checker personnel. Reports and documents shall be checked for technical and editorial accuracy before they are submitted to the Buyer for any review. The A-E shall internally approve final $\mathrm{CD}$ drawing modifications and sketches, reports, and documents submitted for Buyer acceptance. The A-E shall have written procedures in place that delineate the requirements for reviewing, checking, technical editing, and approval of documents before issuance. These procedures shall be issued to the Buyer for review during work plan development.

Acceptance by the Buyer is the act of reviewing an activity or document, and acknowledging that it may be used for the purpose intended at that time. Acceptance by the Buyer does not ensure that future changes will not be required, and does not convey or imply approval, or assumption of responsibility for the activity or document. The originator remains fully responsible for all aspects of the activity or document, for fulfilling all specifications, and for any other obligation or liability otherwise arising under a specification, agreement, or contract.

\subsubsection{Document Transmittal}

Unless otherwise agreed upon, transmittal of record documents shall include one reproducible and 10 copies. For documents larger than 21.6 by $27.9 \mathrm{~cm}$ ( 8.5 by 11 in.), full-size, 
photo-quality reproducibles shall be included. Transmittal of record documents produced electronically shall include indices that identify directory and data set file names. Transmittals shall be documented on a suitable, sequentially numbered form that contains a standard document identification number, distribution list, and space for reviewers to note the disposition of listed attachments in accordance with DOE Order 1324.5B, Records Management Program (DOE 1995b) and the A-E Project document transmittal procedure. Any electronic design media used, modified, or generated in CD shall be provided to the Buyer when the CDR is completed.

\subsubsection{Record Files}

Record files with current and previous revisions shall be maintained for record documents in accordance with the A-E's QA requirements. At the conclusion of $C D$, the Buyer will advise the A-E of the files' disposition. The A-E shall keep duplicate copies of data to meet code or legal requirements.

\subsection{RECORDS MANAGEMENT PROCEDURES}

The A-E shall develop (based on its internal procedures) and submit for the Buyer's Project Office review a records management procedure that establishes the controls for collecting, tracking, and maintaining records for the $\mathrm{CD}$ effort. This guidance/procedure shall include receipt, transmittal, processing, disposition, and storage requirements. These procedures shall be submitted to the Buyer for concurrence.

\subsection{SYSTEMS ENGINEERING MANAGEMENT}

The A-E shall prepare a preliminary systems engineering management (SEM) approach that defines a method for conducting SEM for the later design phases. The approach shall include outlines and scope of the systems engineering management plan for managing systems engineering activities on the Project and be included in the CDR. The A-E's systems engineering management plan outline and approach shall generally follow the preparation guidelines in DOE Order 430.1, Life-Cycle Asset Management (DOE 1995a) and be consistent with, and support, the Buyer's Project Office Project management approach.

\subsection{QA}

The A-E shall use an established QA Program that is commensurate with the CD effort. The A-E shall submit the CD QA approach and guidelines for review by the Buyer's Project Office. The QA Program shall also comply with those sections of 10 CFR 830.120, "Quality Assurance," that are relevant to the particular tasks being performed. 
HNF-SD-W464-SOW-001

Revision 0

This page intentionally left blank. 


\subsection{DESCRIPTION OF REQUIRED SERVICES}

The A-E is the fully responsible design agent for translating Project requirements into a cost-effective $C D$ that satisfies all programmatic and technical requirements. This section describes the tasks that the Buyer has specifically identified as necessary for CD development but it does not include "all technical tasks" that are necessary to produce an acceptable CD. The A-E is required to supplement this task list by adding other necessary work items or upgrading the Buyer's work scope definition of identified tasks, as necessary, to satisfy its assessment of the effort needed to produce an acceptable $\mathrm{CD}$ that satisfies all technical and quality requirements.

\subsection{DESIGN OBJECTIVES}

The overall $\mathrm{CD}$ objective is to develop an initial Project baseline, consistent with program goals, that defines the Project cost, schedule, and technical performance. The CDR effectively forms a significant fraction of the initial Project DRB through the development of supporting documents as identified in Section 2.3.

The principal objectives of the $\mathrm{CD}$ are as follows.

- Develop SNF CSB retrofit modifications and transportation system designs to a level of detail to develop budget validation documents in accordance with DOE Order 430.1 .

- The A-E shall identify key transportation and CSB features and subsystems and adequately analyze these systems to ensure, in CD, that the Phase I solidified HLW Interim Storage mission, project objectives, and key requirements can be satisfied.

- In addition, the A-E shall ensure that the Project does not compromise any aspect of SNF storage and retrieval.

- Identify and perform engineering assessments in areas for which further Project definitions or modifications are required to reduce technical uncertainties and Project cost.

- Accomplish the major stage of the Project and Hanford Site interface definitions using the systems engineering approach.

- Establish the initial Project baseline including cost, schedule, and technical scope, and document them in a CDR.

- Issue a CDR. 
HNF-SD-W464-SOW-001

Revision 0

\subsection{WORK ITEMS}

The A-E is required to perform the following Project activities, at a minimum.

1. Review preliminary Project information provided by the Buyer (Section 2.5). The Project information will be transmitted to the A-E at time of contract (work order issuance) award. Prepare a summary assessment (report or presentation) that describes the A-E's understanding of the DRD, as-built design documents of the SNF CSB Project, and HLW Interim Storage Project documents, and identify those items or areas that require further clarification. Specifically include a separate assessment (report or presentation) that summarizes the degree to which preconceptual and Project definition engineering studies are adequate to reduce $\mathrm{CD}$ work scope. Preconceptual and Project definition engineering studies that contain sufficient quality and detail to partially reduce the work scope or fully eliminate individual $\mathrm{CD}$ work items shall be reflected in the $\mathrm{CD}$ work plan. In addition, review the Buyer's Receipt Acceptance/Waste Qualification strategy, to be provided April 30, 1997, and identify key systems/subsystems necessary for Receipt Acceptance/Waste Qualification, if any, and include them in the CD. Cost estimates for Receipt Acceptance/Waste Qualification-related system design/equipment/systems shall be included in the CDR and summarized.

2. Prepare a CD work plan, in accordance with Section 3.3, that describes the means by which the A-E will prepare the $C D$, including specific technical tasks identified in this SOW, and provide the services defined in this SOW. Itemize in a summarized fashion the technical depth that will be provided in the $\mathrm{CD}$, such as plant arrangements, specific design support analysis, CD deliverables (including the CDR), electrical one-line diagrams, flow diagrams (process/physical), piping and instrumentation diagrams, other relevant depictions, etc. These CD media shall adequately provide the Solidified HLW Interim Storage System design by identifying new and modified facility features, plant arrangements, process equipment, design support analysis, etc. The $\mathrm{CD}$ work plan shall also identify major systems/subsystems and cost/schedule estimating methods to be used for these and other minor systems, and list known input and assumptions. The $\mathrm{CD}$ work plan shall also document all assumptions to be used for the design work and key A-E personnel and experienced technical staff.

3. Prepare a CDR and establish the Project cost estimate with contingency and the master schedule. The arrangement, content, and format of the CDR shall be determined by the A-E with the concurrence of the Buyer's Project Office. The minimum requirements for a CDR are provided in DOE Order 430.1, Life-Cycle Asset Management (DOE 1995a). The content of the CDR shall be determined by the A-E and the Buyer during work planning. The CDR shall describe the solidified HLW transportation and storage systems, and address the risks and uncertainties associated with the selected design concept(s). To ensure the CDR complies with the DRD and any Buyer-approved changes, the CDR submitted for Buyer approval 
shall include documentation of how the A-E's CD addresses the Project design requirements in the DRD. As part of the CDR, the A-E shall evaluate the present Project schedule (see Section 1.5) and recommend modifications as necessary.

4. Prepare a time-phased logic network Project master schedule that is supported by a basic subnetwork schedule covering all phases of the Project (i.e., design, bid package preparation, bid periods, construction phases, and as-built). Schedules shall identify the critical path and the construction packages, and shall be consistent with the work breakdown structure (WBS) provided by the Buyer. Prepare a Project summary schedule and a Project milestone schedule in bar chart form based on information developed in the logic network schedules. Time scales of these schedules shall be appropriate for the level of detail presented.

5. Prepare a total estimated Project cost (total estimated cost and total Project cost) at the WBS level, based on parametric cost estimates, material takeoffs, and vendor quotations. The estimate shall use rates included in approved Hanford Site construction estimate factors and include the basis for each item, such as vendor quotations, SNF cost estimates, method of arriving at Project cost estimate, etc. The A-E shall develop the total estimated cost and maintain the Project cost database. The Project cost estimate data shall be electronically stored, and shall be capable of being sorted within its code of accounts. The estimating software shall be capable of providing information sorts by DOE code, WBS, work package, facility, system, and Construction Specification Institute formats. The A-E shall coordinate needed input from other Project participants to develop the total Project cost estimate. This effort will be conducted through the Buyer's Project Office.

6. Perform constructability assessment and evaluation of the construction schedules for CSB subsystems for which construction issues are thought to exist and which are perceived to have major cost or schedule impact. Perform an engineering evaluation to identify and confirm that a viable concept(s) exists for the installation of required retrofit features in the SNF CSB (e.g., louvers, retrofit of HCS Annex, storage tubes for Vaults 2 and 3). Where more than one retrofit installation alternative exists, an ROM cost estimate shall be prepared for each alternative to ascertain the most costeffective alternative. Alternatives will be submitted to the Buyer for review and concurrence before initiation of costly and or time-consuming work. Prepare a preliminary list of items that require a long lead time for equipment design, fabrication, and procurement. Place emphasis on identifying equipment that requires advance procurement action to support the construction schedule.

7. Perform all engineering tasks necessary to develop a Project CD that depicts new and modified facility features, transportation system, and equipment arrangements. Conceptual design drawings/sketches (with related design analyses) shall be prepared and issued to document new and modified design features and related design analyses, and to establish the engineering baseline for process systems, support systems, and facilities in a cost-effective manner. As a minimum, the 
following types of information shall be developed as required to depict new installation, and retrofit modification, of structures, systems, and components. To the maximum extent possible, use existing engineering documents and studies to develop the CDR. Rework from such documents shall be minimized.

- Site plans (SNF Project information)

- Site layout (SNF Project information)

- Architecture (SNF Project information)

- General arrangement (SNF Project information)

- Space allocation

- Electrical

- Mechanical

- Communication system (SNF Project information)

- Fire detection/protection (SNF Project Fire Hazards Analysis and any necessary system modification)

- HVAC

- Distributed control system

- Transportation systems

- Support systems

- Outline specification.

8. Prepare preliminary Project interface control information and include it in the CDR. Identify all Solidified HLW Interim Storage System interfaces between it and facility systems, and facilities outside the plant. Direct particular emphasis toward interface requirements related to the solidified HLW production facilities and Hanford Site infrastructure. Define the following, at a minimum:

- Physical interface points and requirements, for new and retrofit facility modifications, including transportation systems (e.g., size requirements; handling features, such as lifting pintle design, flow capacity, pressure, material of construction, etc.) 
- Functional interfaces such as effluents, solid waste, support facilities, etc., not covered by the existing facility operation

- Technical requirements of interfacing facilities/system for new and retrofit modifications.

Where interface information is unavailable, but required for design, it shall be so noted in the interface control document.

9. Provide a preliminary safety evaluation of safety aspects/features that could significantly impact cost. Review the SNF PSAR (WHC 1996) and the Project Preliminary Safety Evaluation (Kidder 1996) and prepare a brief report that provides potential differences and impacts. This report shall include, but not be limited to, an assessment of CSB hazards classification, a summary-level listing of radioactive and hazardous material inventories, potential accident scenarios, and specific safetyrelated design criteria applicable to the Project and a general description of how the design will meet these criteria.

10. Prepare topical reports to document significant technical findings and/or describe significant design optimization studies and recommendations. These topical reports shall be summarized in a CDR. For each individual engineering task, prepare a summary task plan that identifies the specific areas to be addressed. The task plan shall clearly describe the work scope, resource requirements, assumptions, schedule, and deliverables. Each report shall clearly summarize the results of the studies and design recommendations. Special tasks that require topical reports shall include, but not be limited to, the following.

a. Perform a life-cycle cost estimate using established methodology on proposed facility and design concepts including systems. The Buyer shall review and concur with the format and approach.

b. Develop a design risk assessment document that discusses all technical issues (with risk) identified during CD and include a summary discussion in the CDR relative to disposition cost impacts and how they are resolved in the cost estimate (contingency). The document shall, to the extent possible, quantify the risk and recommend an approach for cost and schedule to mitigate the risk. The document shall show constraints on the Project schedule.

c. Perform appropriate shielding analyses and issue a topical report that describes findings and future work items. To ensure that standardized, validated methods are followed for shielding calculations, the Buyer will review and concur with the A-E's shielding design code(s). In addition, the Buyer will review and concur with source terms, bases for assumptions, and modeling done in support of shielding design to ensure codes are properly applied and that the principles of "as low as reasonably achievable" have been 
implemented. Shielding calculations may be reviewed by the Buyer before the A-E uses the calculated values in the $C D$.

d. Evaluate whether the existing (i.e., as designed by the SNF Project) safety classifications of CSB systems, components, and structures are sufficient for the Project storage mission. Prepare and issue a preliminary safety class designation list with basis.

e. Perform a conceptual engineering assessment of available transportation systems and equipment for solidified HLW products and provide it to the Buyer for review. The existing SNF CSB design is based on a specific concept for the receipt and movement of MCOs that contain SNF. To the degree practical, it is desirable to adapt this concept to the physical process flow of solidified HLW. This task shall survey the SNF CSB concept and ascertain its potential for adaptation to solidified HLW. If the transportation casks and/or equipment are found to be unusable for accepting and transporting solidified products from privatized production facilities, alternate concepts shall be developed.

Develop a physical process flow (time/motion) description for solidified HLW onsite transport (from production facilities to storage facility) and the complete emplacement into interim storage (i.e., operational steps, sequences, durations, etc.). Determine the number of onsite casks and transporters required to support the receipt rate. At the time of acceptance, the immobilized HLW canister or separated cesium container is contained within an onsite shipping cask that is loaded on a transportation vehicle at the privatized vendor facilities.

f. Perform a conceptual engineering evaluation to identify viable concepts for canister rework (i.e., overpack capabilities). To the degree practical, it is desirable to integrate these features into the SNF Hot Conditioning Annex (as a retrofit modification). Should such dual use not be viable or cost-effective, alternate concepts to provide for canister rework shall be developed. This work element includes development of an overpack container concept and the operations/equipment necessary to seal, decontaminate, and survey for external surface contamination.

g. Perform necessary engineering evaluation (modeling, etc.) to ensure that the canister centerline temperature (immobilized HLW and separated cesium containers) can be maintained below required maximum temperatures in the selected tube design and existing vault configuration. This task is important to ensure that the CSB can fulfill its intended mission relative to the Phase I solidified HLW Interim Storage mission. If practical/prudent, engineering evaluations (natural convection modeling, etc.) performed for the HWVP 


\section{HNF-SD-W464-SOW-001}

Revision 0

Project and SNF Project, or studies to ascertain viability to store cesium/strontium capsules in a vault, should be used to resolve this concern.

11. As part of design development for process systems, support systems, and facilities, the A-E shall perform additional (non-routine design) special studies/tasks as required by the A-E or as directed by the Buyer to evaluate alternatives. Such studies shall be documented in topical reports that contain technical findings, tradeoffs, developments, analysis performed, and recommendations. The A-E, with concurrence from the Buyer, shall develop a standard format for use in preparing study reports. A detailed outline, including alternatives to be evaluated, work statements, decision hold points, and cost and schedule of each study, in the standard format, shall be submitted for Buyer approval. The initial work plan shall not include cost for these studies; the budget will be provided under separate work order upon Buyer approval of work scope. Once approved for execution, each task shall be monitored under a traceable budget account.

Alternatives selected (Buyer approval of selected alternative required) for evaluation in a study shall not necessarily be limited to the requirements of the baseline documents. Alternatives shall be documented and maintained, and shall become part of the final documentation or report file. Proposed changes to the baseline documents that are necessary to implement the approved study recommendation shall be submitted for Buyer approval before the changes are implemented. These studies, in addition to studies performed during the normal course of the A-E's work, shall be reviewed in accordance with the design review process. The potential cost savings associated with each study alternative shall be quantified by performing an ROM cost estimate in conjunction with study preparation. Each ROM cost estimate shall be prepared at the direct cost level.

12. Provide HVAC and material balances, process time/motion analyses, physical/mechanical flowsheets and flow diagrams, and preliminary piping/ instrumentation/control system diagrams as necessary to support the CD.

13. Develop a preliminary process control philosophy, potential failure recovery features, and process operation sequences as required to define new features and retrofit modifications.

14. Develop and define basic design features and operation philosophies for new and modified process supporting systems. Design features, including capacity, requirements, space allocations, design assumptions, and waste minimization, shall be documented.

15. Participate in special study tasks, technical services, discussions, and meetings required on an "as-needed" basis to support the Project. Provide assistance with briefings and formal presentations, as requested. The estimated frequency of presentations is two per month. Assist with generation of briefing material 


\section{HNF-SD-W464-SOW-001 \\ Revision 0}

(narratives, cost data, and graphics), participate in portions of the briefing, and respond to actions (via agreement/commitment documentation and meeting minutes) for which the A-E is made responsible. The work plan shall not include cost for this activity in excess of $\$ 20,000$.

16. Provide support for other special need items, such as independent engineering reviews, audits and surveillances, and independent cost estimate reviews, as required. The work plan shall not include cost for this activity in excess of $\$ 20,000$.

\subsubsection{Design End Items}

Table 4-1 shows deliverable design end items for the CD. The table also identifies responsibilities, approval levels, and schedule information.

\subsubsection{Design Media Transmittal}

All information and design media developed during the CD phase, including all support data necessary to understand the basis and assumptions for the design, must be forwarded to the Buyer for use as a basis in future design phases. 
Table 4-1. Design End Items.*

\begin{tabular}{|l|c|c|l|}
\hline \multicolumn{4}{|c|}{ Conceptual design activities } \\
\hline Item & A-E & Buyer & \multicolumn{1}{c|}{ Schedule } \\
\hline Preliminary information review report & P/A & R/Ac & Within 15 calendar days ANTP \\
\hline Work plan & P/A & R/Ac & Within 30 calendar days ANTP \\
\hline Quality assurance approach & P/A & R/Ac & Within 45 calendar days ANTP \\
\hline Systems engineering approach & P/A & R/Ac & Within 45 calendar days ANTP \\
\hline CDR & P/A & R/Ac & AWP (90\%) \\
\hline CDR drawings & P/R & R & With CDR \\
\hline Project cost estimate & P/R & R & $90 \%$, AWP \\
\hline Project schedule & P/R & R & $90 \%$, AWP \\
\hline Final CDR & P/A & R/Ac & AWP \\
\hline Final Project estimate & P/A & R/Ac & AWP \\
\hline Final Project schedule & P/A & R/Ac & AWP \\
\hline Topical reports, special studies & P/A & R & As required \\
\hline Safety classifications evaluation report & P/A & R/Ac & With CDR \\
\hline Life-cycle cost analysis & P/A & R/Ac & With CDR \\
\hline Risk assessment & P/A & R/Ac & With CDR \\
\hline PSE & P/A & R/Ac & With CDR \\
\hline Drawings and specifications list & P/A & R/Ac & With CDR \\
\hline Shielding calculation methods & P/A & R/Ac & As required \\
\hline
\end{tabular}

*For each deliverable, at minimum one reproducible and 10 copies of the deliverable will be submitted. Additional copies may be requested on a case-by-case basis.

$$
\begin{array}{ll}
\text { A } & =\text { Approve } \\
\text { Ac } & =\text { Accept } \\
\text { A-E } & =\text { Architect-Engineer } \\
\text { ANTP } & =\text { After notice to proceed } \\
\text { AWP } & =\text { In accordance with approved work plan } \\
\text { CDR } & =\text { Conceptual design report } \\
\text { P } & =\text { Prepare } \\
\text { PSE } & =\text { Preliminary safety evaluation } \\
\text { R } & =\text { Review }
\end{array}
$$


HNF-SD-W464-SOW-001

Revision 0

This page intentionally left blank. 


\section{HNF-SD-W464-SOW-001 \\ Revision 0}

\subsection{REFERENCES}

10 CFR 830.120, "Quality Assurance," Code of Federal Regulations, as amended.

ANSI/ASME, 1989, Quality Assurance Program Requirements for Nuclear Facilities, ANSI/ASME NQA-1-1989, American National Standards Institute/American Society of Mechanical Engineers, New York, New York.

Calmus, R. B., 1996a, High-Level Waste Interim Storage Architecture Selection Design Report, WHC-SD-WM-TA-183, Rev. 0, Westinghouse Hanford Company, Richland, Washington.

Calmus, R. B., 1996b, Design Requirements Document for the Interim Store Phase I Solidified HLW, WHC-SD-WM-DRD-012, Rev. 0, Westinghouse Hanford Company, Richland, Washington.

Calmus, R. B., 1996c, Solidified High-Level Waste Interim Storage Alternative Analysis and Path Forward Recommendation, WHC-SD-WM-SP-011, Rev. 0, Westinghouse Hanford Company, Richland, Washington.

Deffenbaugh, M. L., 1996, Environmental Requirements Checklist for the High-Level Waste Storage Project Canister Storage Building (Letter number 70100-96-004 to K. C. Burgard, November 4), Lockheed Martin Hanford Corporation, Richland, Washington.

DOE, 1995a, Life-Cycle Asset Management, DOE Order 430.1, U.S. Department of Energy, Washington, D.C.

DOE, 1995b, Records Management Program, DOE Order 1324.5B, U.S. Department of Energy, Washington, D.C.

Fluor, 1996a, Canister Storage Building HLW Implementation Study, prepared by Fluor Daniel, Inc., for Westinghouse Hanford Company, Richland, Washington.

Fluor, 1996b, Canister Storage Building HLW Implementation Study Supplemental Report, prepared by Fluor Daniel, Inc., for Westinghouse Hanford Company, Richland, Washington.

Kidder, R. J., 1996, Canister Storage Building Evaluation of Nuclear Safety for Solidified HighLevel Waste Transfer and Storage, WHC-SD-WM-TI-781, Rev. 0, Westinghouse Hanford Company, Richland, Washington. 


\section{HNF-SD-W464-SOW-001}

\section{Revision 0}

RL, 1996, TWRS Privatization Request for Proposals, DE-RP06-96RL13308, U.S. Department of Energy, Richland Operations Office, Richland, Washington.

WHC, 1996, Canister Storage Building Safety Analysis Report - Phase 3, WHC-SD-SNF-RPT005, Rev. 5, Westinghouse Hanford Company, Richland, Washington. 


\subsection{GLOSSARY}

\section{ABBREVIATIONS AND ACRONYMS}

$\begin{array}{ll}\text { ADS } & \text { Activity Data Sheet } \\ \text { A-E } & \text { Architect-Engineer } \\ \text { ANTP } & \text { after notice to proceed } \\ \text { AWP } & \text { in accordance with approved work plan } \\ \text { CADD } & \text { computer-aided design and drafting } \\ \text { CD } & \text { conceptual design } \\ \text { CDR } & \text { conceptual design report } \\ \text { CSB } & \text { Canister Storage Building } \\ \text { CWBS } & \text { contractor work breakdown structure } \\ \text { D\&D } & \text { decontamination and decommissioning } \\ \text { DOE } & \text { U.S. Department of Energy } \\ \text { DRB } & \text { design requirements baseline } \\ \text { DRD } & \text { design requirements document } \\ \text { FYWP } & \text { fiscal year work plan } \\ \text { HLW } & \text { high-level waste } \\ \text { HVAC } & \text { heating, ventilating, and air conditioning } \\ \text { M\&I } & \text { Management and Integration } \\ \text { MHM } & \text { multi-canister overpack handling machine } \\ \text { MYPP } & \text { multiyear program plan } \\ \text { QA } & \text { quality assurance } \\ \text { PMB } & \text { performance measurement baseline } \\ \text { PSE } & \text { preliminary safety evaluation } \\ \text { PSWBS } & \text { Project summary work breakdown structure } \\ \text { RL } & \text { U.S. Department of Energy, Richland Operations Office } \\ \text { ROM } & \text { rough-order-of-magnitude } \\ \text { SNF } & \text { Spent Nuclear Fuel } \\ \text { SOW } & \text { Statement of Work } \\ \text { TWRS } & \text { Tank Waste Remediation System } \\ \text { WBS } & \text { work breakdown structure } \\ \text { WPPSS } & \text { Washington Public Power Supply System } \\ & \end{array}$




\section{HNF-SD-W464-SOW-001}

Revision 0

This page intentionally left blank.

GL-2 


\section{DISTRIBUTION SHEET}

\begin{tabular}{|c|c|c|c|c|c|}
\hline \multirow{2}{*}{$\begin{array}{l}\text { To } \\
\text { Distribution }\end{array}$} & \multirow{2}{*}{\multicolumn{3}{|c|}{$\begin{array}{l}\text { From } \\
\text { J. A. Voogd }\end{array}$}} & \multicolumn{2}{|l|}{ Page 1 of 1} \\
\hline & & & & \multicolumn{2}{|c|}{ Date $12 / 16 / 96$} \\
\hline \multirow{2}{*}{\multicolumn{4}{|c|}{$\begin{array}{l}\text { Project Title/Work Order } \\
\text { Statement of Work for Conceptual Design of Solidified High-Level } \\
\text { Waste Interim Storage System Project (Phase I) } \\
\text { HNF-SD-W464-SOW-00 I }\end{array}$}} & \multicolumn{2}{|c|}{ EDT No. 619110} \\
\hline & & & & \multicolumn{2}{|l|}{ ECN No. N/A } \\
\hline Name & MSIN & $\begin{array}{c}\text { Text } \\
\text { With All } \\
\text { Attach. }\end{array}$ & Text Only & $\begin{array}{l}\text { Attach./ } \\
\text { Appendix } \\
\text { Only }\end{array}$ & $\begin{array}{c}\text { EDT/ECN } \\
\text { Only }\end{array}$ \\
\hline
\end{tabular}

\section{Lockheed Martin Hanford}

H. L. Boston

G3-21

K. C. Burgard

S. R. Nelson

J. A. Voogd

Central files (orig. +1)

H5-27

E6-62

H5-27

A3-88

$X$
$X$
$X$
$X$

Numatec Hanford

L. J. de Lamartinie

H5-61

H5-27

$\mathrm{x}$

C. A. Petersen

$x$

SGN Eurisys Services Corporation

R. B. Calmus

L. A. Fort

H5-27

H5-61

D. W. Hamilton

B4-51

$x$
$x$
$x$

